\title{
In vitro anticancer activity of ethanol extract of Adhatoda vasica Nees on human ovarian cancer cell lines
}

\author{
J. N. Nikhitha' ${ }^{1}$ K. S. Swathy ${ }^{2}$ and R. Pratap Chandran ${ }^{1 *}$ (D)
}

\begin{abstract}
Background: Ovarian cancer causes more deaths than any other cancer of the female reproductive system because there is no effective screening and most women are diagnosed at advanced stages. The probability of survival at 5 years is less than $30 \%$, and the limitation is that it will not respond to chemotherapy protocol and surgery as well. Moreover, some evidence have shown potential anticancer properties of flavonoids, protective chemicals in plant foods, such as being an antioxidant, antiestrogenic, antiproliferative, and antiinflammatory. In this study, the anticancer activity of crude ethanol extracts of leaves from Adhatoda vasica was investigated.

Results: By the application of a cell-based assay, the LC 50 value of the A. vasica which showed anticancer effect was used for further studies. The cell line treated with LD 50 value of $A$. vasica extracts was observed for $0 \mathrm{~h}, 24 \mathrm{~h}$, and $48 \mathrm{~h}$ to reveal the inhibition of the metastatic property in treated PA1 cells. The mRNA isolated from the teratocarcinoma PA1 cells treated with the A. vasica extract was further converted to CDNA and was amplified for the analysis of the p53 gene, p21 gene, and GAPDH gene expression. The expression in treated cells and the untreated control indicated the activity of the A. vasica extract against the ovarian cancer.
\end{abstract}

Conclusion: The present study suggested the antiproliferative and antimetastatic effects of medicinal plant $A$. vasica on PA1 cells.

Keywords: Adhatoda vasica, Anticancer, Cell line, Ovarian cancer, Teratocarcinoma

\section{Background}

Ovarian carcinoma could originate from any of three potential sites: the surfaces of the ovary, the fallopian tube, or the mesothelium-lined peritoneal cavity. During initial tumorigenesis, ovarian malignant cells undergo an epithelial to mesenchyme transition, which involves a change in cadherin and integrin (marker) expression and up-regulation of photolytic pathways $[1,2]$. The initial steps of metastasis are regulated by a controlled interaction of adhesion receptors and proteases, while late metastasis is characterized by the oncogene-driven fast

\footnotetext{
* Correspondence: drpratapchandran@yahoo.co.in

'Department of Biotechnology and Research, K. V. M. College of Science and Technology, Kokkothamangalam P.O., Cherthala 688527, Alappuzha District, Indore, Kerala State, India

Full list of author information is available at the end of the article
}

growth of tumor. The prolonged use of platinum-based chemotherapy often leads to drug resistance, which causes the ovarian cancer patient to relapse and potential death $[3,4]$. Therefore, there is an urgent medical need for breakthrough drugs with an effective therapeutic impact on ovarian cancer [5]. Since phytochemicals have been used over years as treatment for various diseases, because of their huge chemical diversity and wide range of biological activity, subsequently around $60 \%$ of the currently used anticancer drugs were derived from natural sources including plants [6, 7]. Hence, evolved the rationale of treating cancer using secondary metabolites isolated from the plant extracts with the most effective mechanisms that enhance P53 protein expression, reducing the expression of proteins P27, P21, and $\mathrm{NF} K \mathrm{~B}_{\mathrm{B}}$ and induction of apoptosis, inhibition of the

\section{Springer Open}

(c) The Author(s). 2021 Open Access This article is licensed under a Creative Commons Attribution 4.0 International License, which permits use, sharing, adaptation, distribution and reproduction in any medium or format, as long as you give appropriate credit to the original author(s) and the source, provide a link to the Creative Commons licence, and indicate if changes were made. The images or other third party material in this article are included in the article's Creative Commons licence, unless indicated otherwise in a credit line to the material. If material is not included in the article's Creative Commons licence and your intended use is not permitted by statutory regulation or exceeds the permitted use, you will need to obtain permission directly from the copyright holder. To view a copy of this licence, visit http://creativecommons.org/licenses/by/4.0/. 
PI3K/Akt pathway, and reduction of the level of acid phosphatase and lipid peroxidation of herbal plants that can inhibit cell cycle and proliferation $[8,9]$.

Adhatoda vasica belongs to the family Acanthaceae, commonly known as Adosa, which is found in many regions of India. It has a multitude of uses in traditional Ayurveda. A. vasica is most well known for its effectiveness in cancer treatment. The leaf of $A$. vasica showed a stimulant effect on the cancer cells. A. vasica shows many antispasmodic and expectorant effects and is also used for the treatment of asthma, bronchitis, and other respiratory conditions [10]. The prominent alkaloid found in $A$. vasica leaf is the quinazoline alkaloid known as vasicine. In addition to vasicine, the leaves and roots of $A$. vasica contain the alkaloids l-vasicinone, deoxyvasicine, mainontone, vasicinolone, and vascinol [11]. Alkaloids play a major role as anticancer agents by inhibiting the enzyme topoisomerase which is involved in DNA replication, inducing apoptosis and expression of the $\mathrm{P}^{53}$ gene. The development of novel strategies to re-activate mutant p53 is required to provide clues to effectively treat malignant cancers bearing p53 mutations [12].

The cyclin-dependent kinase inhibitor p21 (also known as $\mathrm{p} 21^{\mathrm{WAF} 1 / \mathrm{Cip} 1}$ ) promotes cell cycle arrest in response to many stimuli, served as both a sensor and an effector of multiple antiproliferative signals. The p21 functions as a mediator of p53 tumor suppressor activity inhibiting cell cycle progression through its inhibitory effect on cyclin-dependent kinase (CDK) cyclin complexes and proliferating cell nuclear antigen (PCNA). The tumor suppressor activity of p21 stemmed from inducing growth arrest, differentiation or senescence, and DNA repair $[13,14]$. Recently, it has become apparent that $\mathrm{p} 21$ can be stimulated by other pathways independent of p53. p21 directly regulates gene expression and other cellular events through protein-protein interactions which are independent of CDKs and PCNA. Recent data suggest a tumorigenic role of p21 in certain contexts relying on its ability to suppress human teratocarcinoma cell line apoptosis and promote the assembly of type-D cyclins with CDK4 and CDK6 [15]. Given that p21 is a tumor suppressor, yet behaving as an oncogene in certain cellular contexts, therefore, targeting p21 or factors regulating its activity for therapeutic intervention may be a promising but challenging task $[16,17]$. The present study was designed to investigate the anticancer activity of $A$. vasica ethanol leaf extract against PAI cell lines $[18,19]$.

\section{Methods}

A. vasica leaf samples were collected from Poojappura, Thiruvananthapuram, Kerala state, India. This plant material was identified by Dr. Shaji P.K., Scientist,
Environmental Resources Research Centre, P.B. No. 1230, P.O. Peroorkada, Thiruvananthapuram, Kerala state, India. All chemicals used in the study were of analytical grade and obtained from Invitrogen, Sigma, and HiMedia Laboratories Private Limited, Mumbai, India. The cell line used in the study was PA 1 (human teratocarcinoma) cell lines which were procured from the $\mathrm{Na}$ tional Centre for Cell Science (NCCS), Pune, Maharashtra, India.

\section{Preparation of crude extracts}

A. vasica leaf was carefully plucked and washed. The washed leaves were air dried and chopped into small pieces. As the leaves get well dried, the leaves get weighed. Twenty grams of dried leaves was then treated with $70 \%$ ethanol kept in a shaker for $24 \mathrm{~h}$. The leaves were squeezed out and air dried. Then, the dried extract was used as the test sample.

\section{Test for alkaloids Dragendroff's test}

$0.25 \mathrm{ml}$ of Dragendroff's reagent was added to the previous mixture for precipitation, and the precipitate was centrifuged over $5 \mathrm{~min}$ at $3000 \mathrm{rpm}$ and then further washed with $0.25 \mathrm{ml}$ of ethanol. The filtrate was discarded and the residue was then treated with $0.25 \mathrm{ml}$ of disodium solution $(1 \% \mathrm{w} / \mathrm{v})$. The brownish black precipitate formed was then centrifuged for $5 \mathrm{~min}$ at $3000 \mathrm{rpm}$. This residue was dissolved in $0.2 \mathrm{ml}$ of concentrated nitric acid, and $0.1 \mathrm{ml}$ was then pipetted out and mixed with $0.5 \mathrm{ml}$ of thiourea solution $(3 \% \mathrm{w} / \mathrm{v})$. The absorbance of this solution was measured at $435 \mathrm{~nm}$ using UV-visible spectrophotometer (Agilent, Cary 60) against a blank containing $0.1 \mathrm{ml}$ of concentrated nitric acid and $0.25 \mathrm{ml}$ of thiourea solution $(3 \% \mathrm{w} / \mathrm{v})$, and the values obtained were interpreted using the standard graph of caffeine to get the milligram equivalents of caffeine [20].

\section{Anticancer effect of $A$. vasica extract against PA 1 cell lines}

PA 1 cell lines were grown in Dulbecco's modified Eagle's medium supplemented with fetal bovine serum (FBS), penicillin, and streptomycin. The cells were subcultured after trypsinization with $0.25 \%$ in $0.5 \mathrm{mM}$ EDTA and were cultured under $5 \% \mathrm{CO}_{2}$ at $37^{\circ} \mathrm{C}$.

\section{Dulbecco's modified Eagle's medium (DMEM) preparation} DMEM $(0.67 \mathrm{~g})$ was suspended in $25 \mathrm{ml}$ tissue culture grade water with constant stirring until the powder was completely dissolved. The water should not be heated, and $0.187 \mathrm{~g}$ of $\mathrm{NaHCO}_{3}$ powder was added and stirred until dissolved. The $\mathrm{pH}$ was adjusted to $0.2,0.3 \mathrm{pH}$ units below the desired $\mathrm{pH}(\mathrm{pH}-7.4)$ using $1 \mathrm{~N} \mathrm{HCl}$ or $1 \mathrm{~N}$ $\mathrm{NaOH}$ since the $\mathrm{pH}$ tends to rise during filtration. The 
final volume was made up to $50 \mathrm{ml}$ with tissue culture grade water. The medium was sterilized immediately by filtering through a sterile membrane filter with a porosity of $0.22 \mu \mathrm{m}$ or less. Positive pressure was used rather than vacuumed to minimize the loss of $\mathrm{CO}_{2}$. Aseptically sterile supplements were added as required, and the desired amount of sterile medium was dispensed into sterile containers. The required medium was then stored at 2 to $8{ }^{\circ} \mathrm{C}$ in dark for further use.

\section{Trypsinization}

It is the process of using trypsin, a proteolytic enzyme which breaks down proteins, to dissociate adhered cells from the vessels in which they were being cultured. The cell lines were washed with phosphate-buffered saline (PBS). Five hundred microliters of trypsin was added in cultured cell lines for $3 \mathrm{~min}$ at $37^{\circ} \mathrm{C}$. After disaggregation, the cells were transferred to another flask and supplemented with media.

\section{Subculturing}

Subculturing involves transferring a small number of cells into a new vessel. A confluent plate was taken for subculturing. For subculturing, firstly, remove media from the flask. The flask was then washed twice with PBS and then $200 \mu \mathrm{l}$ of trypsin (0.25\% in $0.5 \mathrm{Mm}$ EDTA) was added to the flask. Incubation was done for $3 \mathrm{~min}$. Mixing was done properly with a pipette throughout the incubation time. Fresh media were added to the trypsinized cells and mixing was done. One hundred microliters of suspension was transferred to a 24-well plate. Fresh media were added to both the mother flask and the 24-well plate. It was then plated in a humified incubator at $37^{\circ} \mathrm{C}$ with a $5 \% \mathrm{CO}_{2}$ incubator.

\section{Sample addition}

After attaining sufficient confluency, the cells were trypsinized (500 $\mu \mathrm{l}$ of $0.025 \%$ Trypsin in PBS/0.5 mM EDTA solution (Himedia Laboratories, India)) for $2 \mathrm{~min}$ and passaged to $\mathrm{T}$ flasks in complete aseptic condition. The cells were treated with a sample of different concentrations $(100 \mu \mathrm{g}, 50 \mu \mathrm{g}, 25 \mu \mathrm{g}, 12.5 \mu \mathrm{g}, 6.25 \mu \mathrm{g}$ in $500 \mu \mathrm{l}$ of $5 \%$ DMEM) and were incubated for $24 \mathrm{~h}$ before the staining procedure starts.

\section{In vitro cytotoxic effect by sulforhodamine B colorimetric assay \\ Cell fixation and staining}

In the well plate without removing the cell culture, supernatant, $100 \mu \mathrm{l}$ of cold $10 \%$ trichloroacetic acid (TCA), was added and incubated at $4{ }^{\circ} \mathrm{C}$ for $1 \mathrm{~h}$. After which, the plates were washed four times with slow running tap water and any excess water was removed using paper towels. The plate was dried using a blow dryer to completely dry them. Once the plates are dry, $100 \mu \mathrm{l}$ of $0.057 \%$ sulforhodamine B (SRB) solution was added to each well. The stain was allowed to be incubated for 30 min followed by briefly rinsing the plate four times with $1 \%$ acetic acid to remove any excess unbound dye. This was followed by the addition of $200 \mu \mathrm{l}$ of $10 \mathrm{mM}$ Tris base solution $(\mathrm{pH} 10.5)$ to each well. The plates were then placed in a shaker for $5 \mathrm{~min}$ to solubilize the protein-bound dye. The OD was read in a microplate reader at $510 \mathrm{~nm}$.

$$
\text { Percentage viability }(\%)=\frac{\text { Absorbance of test }}{\begin{array}{l}
\text { Absorbance of sample } \\
\times 100
\end{array}}
$$

\section{Migration assay}

PA1 (ovarian cancer) cell lines were maintained in Dulbecco's modified Eagle's medium (Gibco, Invitrogen). The cell line was cultured in a $25-\mathrm{cm}$ tissue culture flask with DMEM supplemented with 10\% FBS, L-glutamine, sodium bicarbonate, and antibiotic solution containing penicillin $(100 \mathrm{U} / \mathrm{ml})$, streptomycin $(100 \mu \mathrm{g} / \mathrm{ml})$, and amphotericin B $(2.5 \mu \mathrm{g} / \mathrm{ml})$. Cultured cell lines were kept at $37^{\circ} \mathrm{C}$ in a humidified $5 \% \mathrm{CO}_{2}$ incubator (NBS Eppendorf Germany).

Exponentially growing cells were trypsinized and seeded at a density of 200,000 cells per well into a 12 well plate for 24-h incubation (approximately 90\% confluent). The scratch wounds were made by a sterile $1-\mathrm{ml}$ pipette tip through a pre-marked line. After removal of the resulting debris from five lineal scratches, the cell monolayer was subsequently rinsed three times with PBS followed by incubation with LD 50 concentration of extracts for $0 \mathrm{~h}, 24 \mathrm{~h}, 48 \mathrm{~h}$, and $72 \mathrm{~h}$.

The wound areas were displayed by taking images just above the interchanges between scratched wound areas' pre-marked lines, and the effect of the sample on wound closure was determined microscopically at $4 \times$ magnification (Olympus CKX41) after incubation. The effect of the sample on wound closure was measured in terms of the area using MRI-ImageJ analysis software.

\section{Gene expression study}

PA 1 cells were cultured in a $25-\mathrm{cm}^{2}$ tissue culture flask with DMEM supplemented with 10\% FBS, L-glutamine, sodium bicarbonate (Merck, Germany), and antibiotic solution containing penicillin $(100 \mathrm{U} / \mathrm{ml})$, streptomycin $(100 \mu \mathrm{g} / \mathrm{ml})$, and Amphotericin B $(2.5 \mu \mathrm{g} / \mathrm{ml})$. Cultured cell lines were added with LD 50 concentration of the sample and were kept at $37^{\circ} \mathrm{C}$ in a humidified $\mathrm{CO}_{2}$ incubator (NBS Eppendorf, Germany). An untreated control was also maintained. 


\section{Isolation of total RNA}

Total RNA was isolated using the total RNA isolation kit according to the manufacturer's instruction (Invitrogen product code 10296010). The addition of TRIzol solution causes the disruption of cells and the release of RNA. Chloroform extraction was performed following centrifugation, exclusively in the aqueous phase, whereas proteins are in the interphase and organic phase. On mixing with isopropanol, RNA gets precipitated as a white pellet on the side and bottom of the test tube.

After attaining $70 \%$ confluency of cells in a 6-well plate (approximately $4 \times 10^{5}$ cells), the cells were treated with samples and incubated for $24 \mathrm{~h}$. A set of untreated control were also incubated at $37^{\circ} \mathrm{C}$ for $24 \mathrm{~h}$ in a $\mathrm{CO}_{2}$ incubator. After incubation, DMEM media were removed aseptically and $200 \mu \mathrm{l}$ of TRIzol reagent was added to the culture well plate and incubated for $5 \mathrm{~min}$. The contents were then transferred to a fresh sterile Eppendorf tube. Two hundred microliters of chloroform was added and shaken vigorously for $15 \mathrm{~s}$ and incubated for 2-3 min at room temperature, followed by centrifugation at $1400 \mathrm{rpm}$ for $15 \mathrm{~min}$ at $4{ }^{\circ} \mathrm{C}$. The aqueous layer was collected and $500 \mu \mathrm{l}$ of $100 \%$ isopropanol was added. It was incubated for $10 \mathrm{~min}$ at room temperature and then centrifuged at $1400 \mathrm{rpm}$ for $15 \mathrm{~min}$ at $4{ }^{\circ} \mathrm{C}$. The supernatant was discarded and the pellet thus obtained was washed with $200 \mu \mathrm{l}$ of $75 \%$ ethanol. It was then centrifuged at $14000 \mathrm{rpm}$ for $5 \mathrm{~min}$ at $4{ }^{\circ} \mathrm{C}$ in a cooling centrifuge (Remi CM12).

The RNA pellet was dried and suspended in TE buffer.

\section{CDNA synthesis and amplification}

The cDNA synthesis was performed using Thermo scientific verso cDNA Synthesis kit (Product code AB1453/A). About $4 \mu$ of $5 \mathrm{X}$ cDNA synthesis buffer, $2 \mu \mathrm{l}$ of dNTP mix, $1 \mu \mathrm{l}$ of anchored Oligo dT, $1 \mu \mathrm{l}$ of RT Enhancer, $1 \mu \mathrm{l}$ of Verso Enzyme Mix, and $5 \mu \mathrm{l}$ of RNA template (1 mg of total RNA) were added to an RNAse-free tube. Then, the total reaction volume was made up to $20 \mu \mathrm{l}$ with the addition of sterile distilled water. The solution was mixed by pipetting gently up and down. The thermal cycler (Eppendorf Master Cycler) was programmed to undergo cDNA synthesis. The cDNA synthesis was employed for $30 \mathrm{~min}$ at $42{ }^{\circ} \mathrm{C}$ and inactivation was employed for $2 \mathrm{~min}$ at $95^{\circ} \mathrm{C}$.

The amplification was done using the Thermostatic amplification kit. The following components were added to a new PCR vial in a PCR workstation: for each $50 \mu \mathrm{l}$ reaction, $25 \mu \mathrm{l}$ of PCR Master Mix (2X), $2 \mu \mathrm{l}$ of forward primer $(0.1-1.0 \mu \mathrm{M}), 2 \mu \mathrm{l}$ of reverse primer $(0.1-$ $1.0 \mu \mathrm{M})$, and $5 \mu \mathrm{l}$ of template DNA $(10 \mathrm{pg}-1 \mu \mathrm{g})$. The components were made up to $50 \mu \mathrm{L}$ with sterile distilled water (nuclease free). Initial denaturation was at $95^{\circ} \mathrm{C}$ for $3 \mathrm{~min}$, followed by denaturation at $95^{\circ} \mathrm{C}$ for $30 \mathrm{~s}$, annealing at $\mathrm{Tm}$ for $30 \mathrm{~s}$, and extension at $72{ }^{\circ} \mathrm{C}$ for 1 min which was repeated for 35 cycles and the final extension at $72{ }^{\circ} \mathrm{C}$ for $5 \mathrm{~min}$. After the amplification, the PCR product was separated by agarose gel electrophoresis. The following are the forward sequence $\left(5^{\prime}->3^{\prime}\right)$ and reverse sequence $\left(5^{\prime}->3^{\prime}\right)$ used in the electrophoresis:

\begin{tabular}{l}
\hline Human bactin-TCACCCACACTGTGCCCATCTACGA(25)[Tm 66.3], \\
CAGCGGACCGCTCATTGCCAATGG(25) [Tm 67.9] \\
Human p 21—GAGGCCGGATGAGTTGGGAGGAG(24)[Tm 69.6], \\
CAGCCGGCGTTGGAGTGGTAGAA(24 [Tm 66.1] \\
Human p 53_CCCCTCCTGGCCCCTGTCATCTTC(24) [Tm 69.6], \\
GCAGCGCCTCACAACCTCCGTCAT(24) [Tm 67.8]
\end{tabular}

\section{Agarose gel electrophoresis}

Agarose gel electrophoresis is a method for separating and visualizing DNA fragments. The fragments are separated by charge and size move through an agarose gel matrix, when subjected to an electric field. The electric field is generated by applying a potential across an electrolyte solution (buffer). When boiled in an aqueous buffer, agar dissolves and upon cooling solidifies to a gel. $1.5 \%$ agarose gel was prepared in $1 \mathrm{x}$ TE buffer and melted in a hot water bath at $90^{\circ} \mathrm{C}$. Then, the melted agarose was cooled down to $45^{\circ} \mathrm{C}$. Six microliters of $10 \mathrm{mg} / \mathrm{ml}$ of ethidium bromide was added and poured into a gel casting apparatus with the gel comb. After setting, the comb was removed from the gel. The electrophoresis buffer was poured into the gel tank and the platform with the gel was placed in it so as to immerse the gel. The gel was loaded with the samples and run at $50 \mathrm{~V}$ for $30 \mathrm{~min}$. The stained gel was visualized using a gel documentation system ( $\mathrm{E}$ gel imager, Invitrogen).

\section{Results \\ Crude extracts}

The extracts of the $A$. vasica plant were done using the cold percolation method using $70 \%$ ethanol as solvent and were kept in a shaker for 48-72 h. Afterwards, they were squeezed using a muslin cloth and the extract was kept for drying. The dried extract was used for the analysis in the whole study.

\section{Qualitative analysis}

The presence of alkaloid was determined using Dragendroff's method and the formation of orange red color indicated a positive alkaloid reaction. 


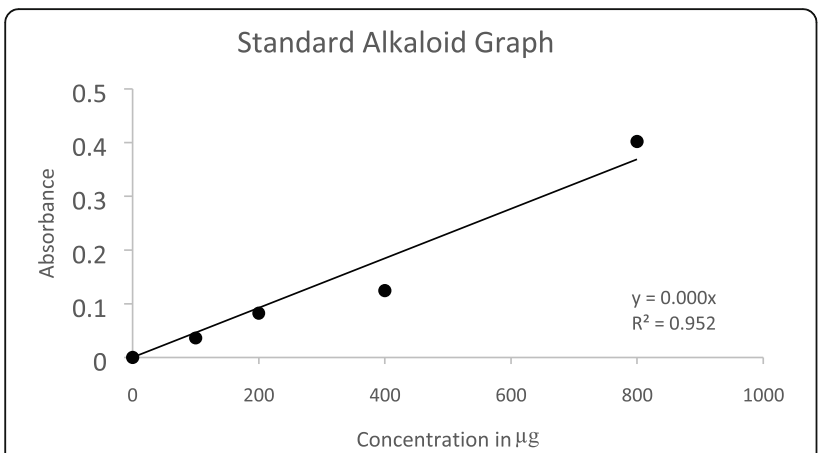

Fig. 1 Alkaloid standard graph

\section{Quantitative analysis}

The extract was further estimated for the determination of the amount of alkaloids present in it from a stock of $10 \mathrm{mg}$ of extract in $1 \mathrm{ml}$ DMSO, and $16.8 \mu \mathrm{g}$ of alkaloid was estimated to be present in $1 \mathrm{mg}$ of extract from the standard graph (Fig. 1).

\section{Sulforhodamine B test}

The A. vasica extract was further treated with PA 1 cell line to check its anticancer effect. The anticancer ability was initially evaluated using SRB staining assay for the cells treated with different concentrations of the $A$. vasica extract, which were initially visualized under a phase contrast microscope for detecting the morphological changes seen in the cells treated with higher concentrations of the extract.

The SRB assay was done to measure drug-induced cytotoxicity and cell proliferation for drug screening applications. From the results, it is observed that as the concentration of the A. vasica extract increased for treatment, the percentage viability of PA1 cancer cells decreased linearly. This observation might highlight the potential anticancer effect of the extract with a LC 50 value of $107.339 \mu \mathrm{g} / \mathrm{ml}$ (calculated using ED50 PLUS V1.0 Software as illustrated in Figs. 2 and 3). As seen in Fig. 2, a gradual decrease in the number of cells (B, C, $D, E$, and $F$ ) and also the morphological changes induced by the extract on PA1 cells such as membrane blebbing, cell shrinkage, etc. when compared to the untreated control (A) indicate the cytotoxic effect of the extract.

\section{Migration assay}

Migration assay is a hallmark assay to determine the effect of anticancer drugs against angiogenesis and metastasis. PA1 cells were created with wound and were treated with LD 50 value of the $A$. vasica extract. The cells were further observed for $0 \mathrm{~h}, 24 \mathrm{~h}$, and $48 \mathrm{~h}$ against an untreated control. The observation implicated that the cells treated with the $A$. vasica extract did not show any growth in the clear area even after $48 \mathrm{~h}$ of incubation, whereas the untreated control was observed with almost complete growth in the clear area, which distinctly reveals that the $A$. vasica extract strongly

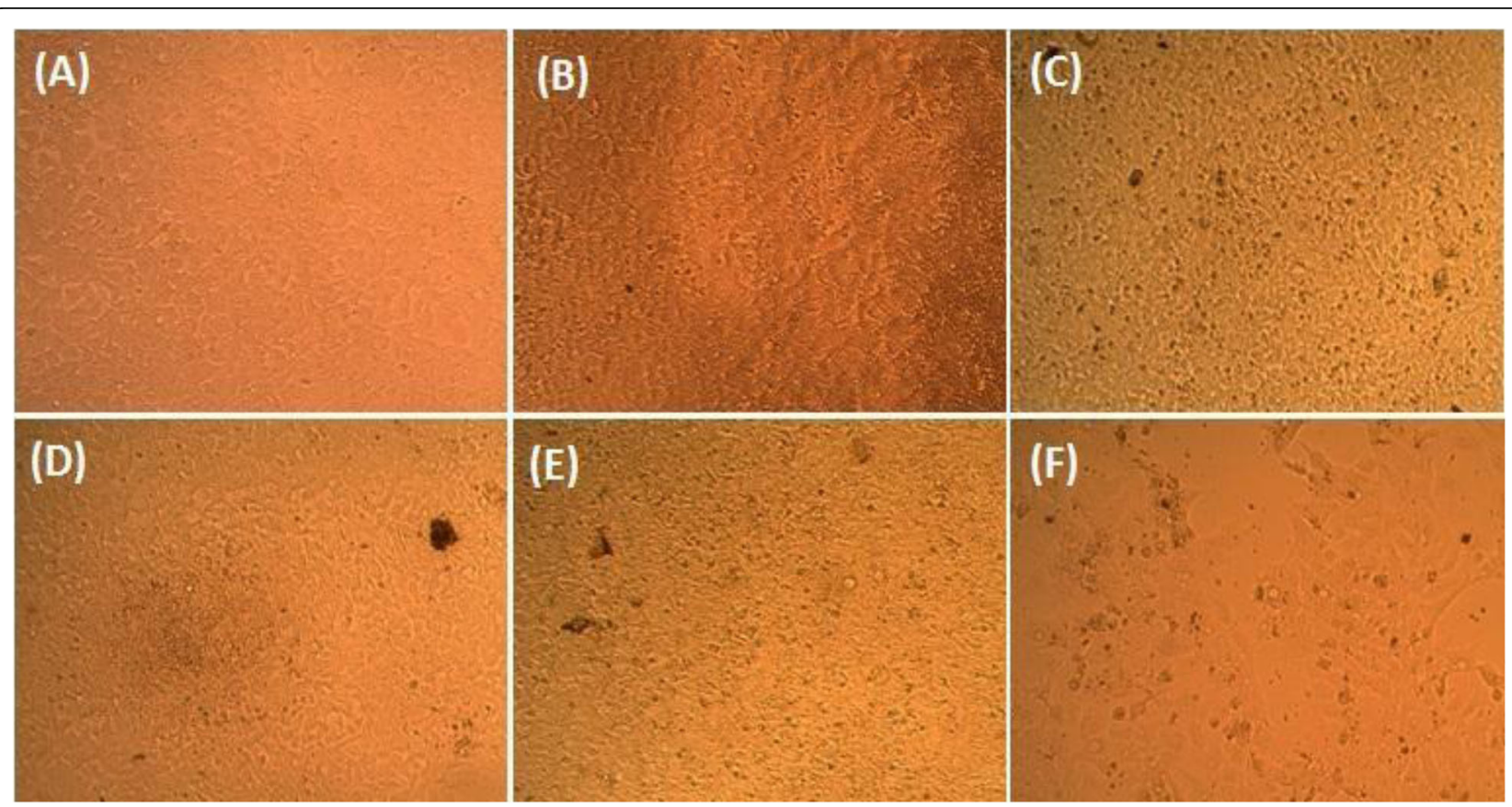

Fig. 2 PA1 cells visualized under a phase contrast microscope. A Control, treated with different concentrations of the sample (in $\mu \mathrm{g}$ ): B $6.25, \mathbf{C}$ $12.5, \mathbf{D} 25, \mathbf{E} 50$, and $\mathbf{F} 100$ 


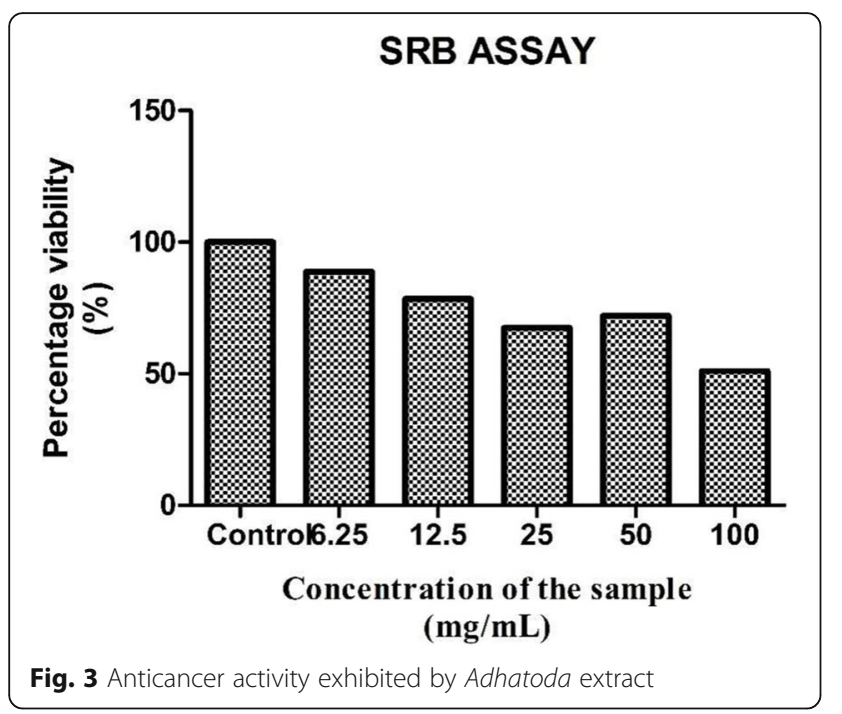

inhibited the metastatic property in treated PA1 cells (Fig. 4).

\section{Gene expression studies}

Gene expression studies were conducted in mRNA isolated from the cells treated with the A. vasica extract, which were further converted to cDNA and were amplified for the analysis of the p53 gene, p21 gene, and GAPDH gene expression (Fig. 5). Figure 5 demonstrates the changes in the expression of p53 and p21 in comparison to the housekeeping gene (GAPDH). Elaboration of it is provided in Figs. 6 and 7 by comparing the expression of both the tumor suppressor genes (p53 and p21) between the untreated and extracttreated cells.

Both p53 and p21 genes showed increased expression in treated cells when compared to untreated control which indicated that the $A$. vasica extract induced an
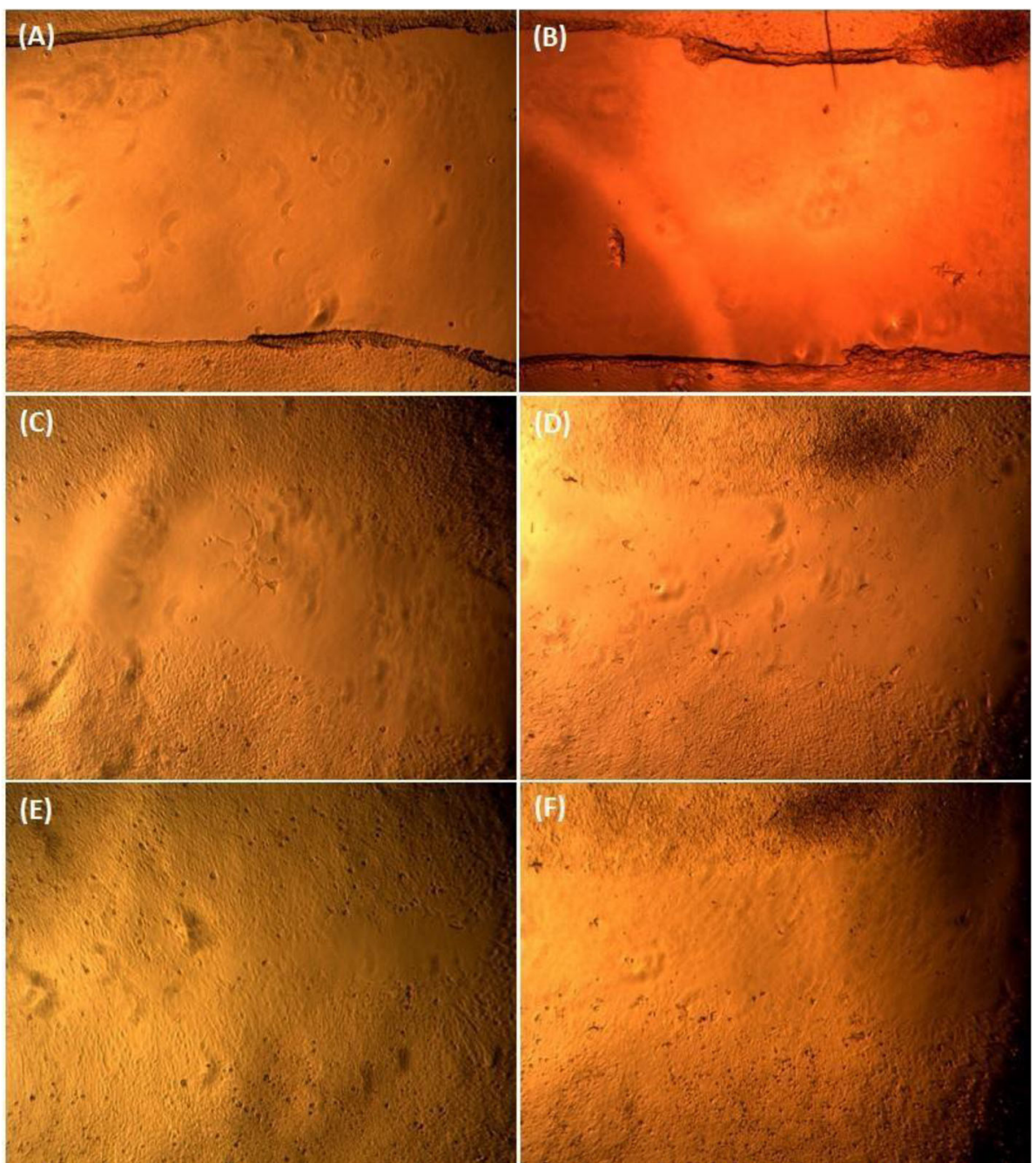

Fig. 4 Phase contrast microscopic images of PA 1 cells after Oth hour of incubation. A Control, B treated 24th hours of incubation, C control, D treated 48th hours of incubation, $\mathbf{E}$ control, $\mathbf{F}$ treated 


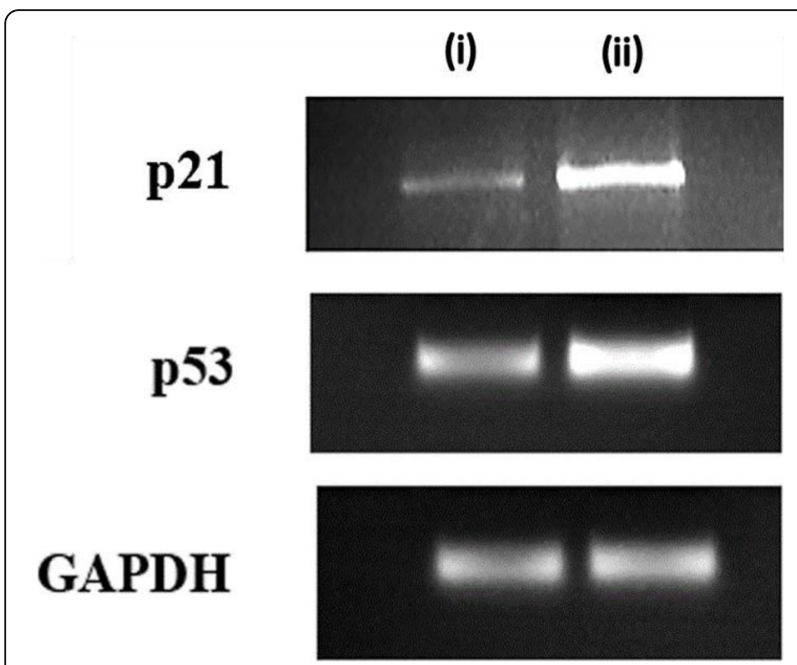

Fig. 5 Gene expression analysis of p21, p53, and GAPDH genes in (i) control cells and (ii) treated cells

increase in expression of both genes in PA 1 cancer cell lines which was confirmed by amplifying GAPDH genes which had comparatively same intensity in both treated cells and untreated control (Figs. 6 and 7).

\section{Discussion}

Among gynecologic malignancies, ovarian cancer is the most lethal and the cellular origin of EOC is not well known. Early theories hypothesized that EOC arises from OSE cells, while more recent ones have proposed that it should no longer be considered as a single disease entity but rather a diverse group of tumors with specific morphologic and genetic characteristics [21].

Cancer chemoprevention with natural phytochemical compounds is an emerging strategy to prevent, impede, delay, or cure malignant diseases [22, 23]. A. vasica Nees (Acanthaceace) is a well-known medicinal plant, and its diverse medicinal activities include cardiovascular protection, abortifacient, antitubercular, antimutagenic, antiulcer, antiasthmatic activities, hepatoprotective, antibacterial, and anticancer activities [24]. Ethanolic extracts of $A$. vasica were screened for the presence of

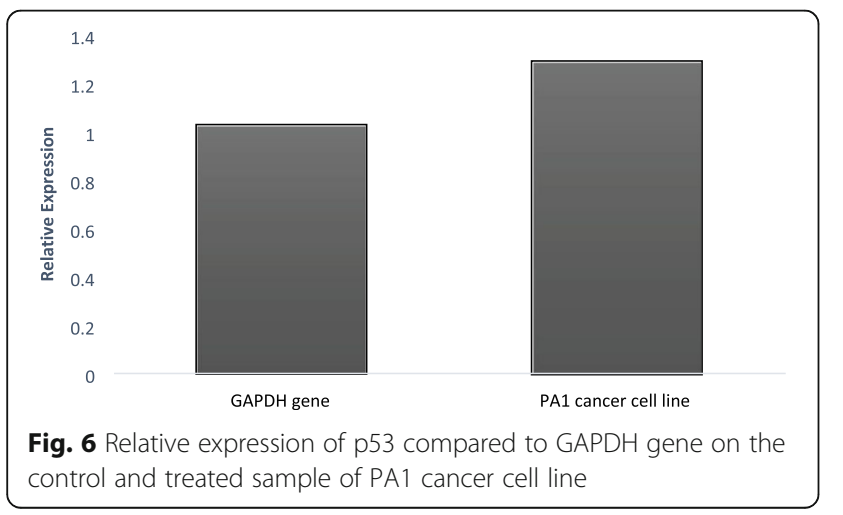

alkaloids reported to be responsible for diverse biological activities $[25,26]$.

The ovarian teratocarcinoma cell line PA-1 demonstrated a single chromosomal aberration and is reported to be a useful model cell line used to demonstrate the anticancer efficacy of the investigated agent in in vitro studies [27-29]. Our results clearly showed a decrease in cell viability as per the method of SRB with an LC 50 value of $107.33 \mu \mathrm{g} / \mathrm{ml}$. The SRB assay has been used since its development in 1990 [30] to inexpensively conduct various screening assays to investigate cytotoxicity in cell-based studies [31]. This method relies on the property of SRB, which binds stoichiometrically to proteins under mild acidic conditions which could be extracted using basic conditions; thus, the amount of bound dye can be used as a proxy for cell mass, which can be extrapolated to measure cell proliferation; hence, EAV is an efficient maneuver to measure the proliferation path of PA1 cell line along with considerable morphological changes similar to that of apoptosis [32].

The study of cell migration in cancer research is of particular interest as the main cause of death in cancer patients is related to metastatic progression. In order for cancer to spread and disseminate throughout the body, cancer cells must migrate and invade through the extracellular matrix (ECM), into blood circulation, and extravasate to form distant foci $[31,33]$. In the current study, we used the cell culture wound closure to determine the antimetastatic properties of EAV. From our results, we observed that when compared with untreated control samples, the migration of PA1 cells is significantly decreased in EAV-treated groups which might indicate the antimetastatic properties of EAV [34, 35].

Reverse transcriptase PCR was done to check the effect of EAV on the expression of p53 and p 21 mRNA which is already reported to be crucial in controlling uncontrolled proliferation and metastasis. p53 is a nuclear transcription factor and transactivates numerous target genes involved in the induction of cell cycle arrest and/or apoptosis. Under normal conditions, p53 is expressed at an extremely low level, which is caused by proteasomal degradation mediated largely by RINGfinger type E3 ubiquitin protein ligase MDM2 p53 which is a nuclear transcription factor with a pro-apoptotic function. Since over $50 \%$ of human cancers carry loss of function mutations in the p53 gene, p53 has been considered to be one of the classical type tumor suppressors and reactivation of p53 can be considered as a therapeutic strategy to combat cancer [12]. Most studies of the mechanisms of p53 action have focused on the transcriptional targets of p53, which mediate p53 functions. $\mathrm{p} 21^{\mathrm{WAF} 1}$ represents one such target, which plays important roles in cell growth arrest and senescence. p21 can 


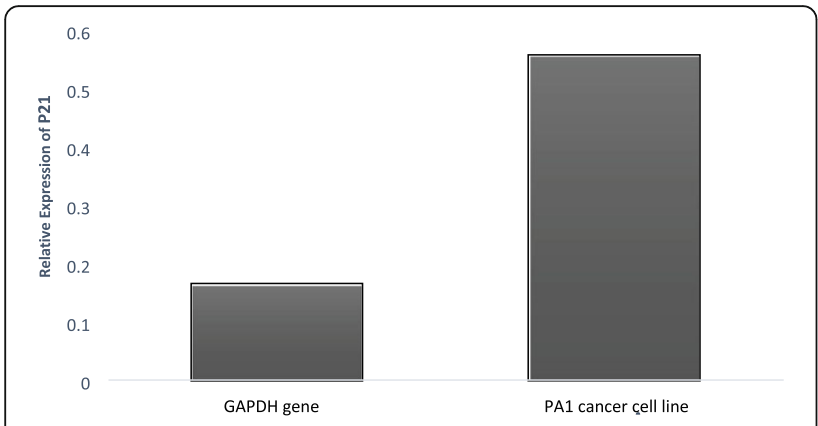

Fig. 7 Relative expression of p21 compared to GAPDH gene on the control and treated sample of PA1 cancer cell line

also suppress cell invasion. Notably, it is reported recently that p21 does not simply serve as a downstream mediator of p53 but cooperates with p53 to suppress cell invasion [36, 37]. From our results, it can be observed that p53 and p21 are activated by treatment with KAv which can be suggested as the major mechanisms of action.

\section{Conclusion}

The continued searching for safer and more effective chemoprevention and treatment is clearly needed for the improvement of the efficiency and to lower the treatment cost for cancer care. In this aspect, targeting cancer with phytochemicals is an area of recent research significance, and the present study aimed to determine the antiproliferative and antimetastatic effects of $A$. vasica. Cold percolation methods of $A$. vasica have given alkaloid-rich fractions which were found to decrease the cell viability of PA1 cells when determined by SRB assay. There were concomitant changes in cell morphology with the concentration of extracts. The antimetastatic activity was confirmed by a cell migration assay. The mRNA expression analysis confirmed the reactivation of p53 and p21 genes upon extracts which were found to have a potent role in the anticancer activity of ethanol extracts of $A$. vasica. Further studies can be conducted in vivo to ascertain the efficiency in animals.

\section{Abbreviations}

$\mathrm{KNO}_{3}$ : Potassium nitrate; $\mathrm{NaHCO}_{3}$ : Sodium bicarbonate; $\mathrm{Na}_{2} \mathrm{CO}_{3}$ : Sodium carbonate; EDTA: Ethylene diamine tetraacetic acid; DMEM: Dulbecco's modified Eagle's medium; FBS: Fetal bovine serum; PBS: Phosphate-buffered saline; TCA: Trichloroacetic acid; SRB: Sulforhodamine B; LD: Lethal dose; TE buffer: Tris-EDTA buffer; dNTP: Deoxynucleotide triphosphate;

DMSO: Dimethyl sulfoxide; EOC: Epithelial ovarian cancer

\section{Acknowledgements}

We gratefully thank Dr. Rajesh Ramachandran, Biogenix Research Centre, Poojappura, Thiruvananthapuram, for giving valuable suggestions and support for the successful completion of this project work.

\section{Authors' contributions}

NJN, SKS, and PCR designed the work, conducted the experiments, analyzed the data, and wrote the manuscript. All authors read and approved the final manuscript.

\section{Funding}

This work did not receive funding from any organization or institution.

Availability of data and materials

All data generated or analyzed during this study are included in this published article.

\section{Declarations}

Ethics approval and consent to participate

Not applicable.

\section{Consent for publication \\ Not applicable.}

\section{Competing interests}

The authors declare that they have no competing interests.

\section{Author details}

${ }^{1}$ Department of Biotechnology and Research, K. V. M. College of Science and Technology, Kokkothamangalam P.O., Cherthala 688527, Alappuzha District, Indore, Kerala State, India. ${ }^{2}$ Department of Biotechnology, Indhira Gandhi College of Arts and Science, Nellikuzhi, Kothamangalam, Ernakulam District, Indore, Kerala State, India.

Received: 18 May 2021 Accepted: 26 July 2021

Published online: 05 August 2021

\section{References}

1. Mousavi SM, Gouya MM, Ramazani R, Davanlou M, Hajsadeghi N, Seddighi Z (2009) Cancer incidence and mortality in Iran. Ann Oncol 20:556-563

2. Balamurugan S, Vijayakumar S, Prabhu S, MorvinYabesh JE (2018) Traditional plants used for the treatment of gynaecological disorders in Vedaranyam taluk, South India - an ethnomedicinal survey. J Tradit Complement Med 8(2):308-323

3. Burges A, Schmalfeldt B (2011) Ovarian cancer: diagnosis and treatment. Dtsch Arztebl Int 108(38):635-641

4. Friedlander $\mathrm{M}$, Trimble $\mathrm{E}$, Tinker $\mathrm{A}$, Alberts $\mathrm{D}$, Avall-Lundqvist $\mathrm{E}$, Brady $\mathrm{M}$ (2011) Clinical trials in recurrent ovarian cancer. Int J Gynecol Cancer 21(4): 771-775. https://doi.org/10.1097//GC.0b013e31821bb8aa

5. Desai AG, Qazi GN, Ganju RK, El-Tamer M, Singh J, Saxena AK, Bedi YS, Taneja SC, Bhat HK (2008) Medicinal plants and cancer chemoprevention. Curr Drug Metab 9(7):581-591. https://doi.org/10.2174/138920008785821657

6. Chandran RP, Manju S, Vysakhi MV, Shaji PK, Nair GA (2016) In vitro cytotoxic activities of leaf extracts of Thespesia populnea and Hygrophilla schulli against Dalton's lymphoma ascites and Ehrlich ascites carcinoma cell lines. Austin J Lung Cancer Res 1(2):1007

7. Disilvestro P, Alvarez Secord A (2018) Maintenance treatment of recurrent ovarian cancer: is it ready for prime time? Cancer Treatment Reviews. 69:5365. https://doi.org/10.1016/j.ctrv.2018.06.001

8. Sakarkar DM, Deshmukh VN (2011) Ethnopharmacological review of traditional medicinal plants for anticancer activity. Int J PharmTech Res 3(1): 298-308

9. Eastman A (2004) Cell cycle checkpoints and their impact on anticancer therapeutic strategies. J Cell Biochem 91:223-231

10. Muruganantham N, Solomon S, Senthamilselvi MM (2015) Anti-cancer activity of Adhatoda vasica flowers against human liver cancer. Am J Pharm Sci 5(6):2712-2715

11. Greenwell M, Rahman PK (2015) Medicinal plants: their use in anticancer treatment. Int J Pharm Sci Res 6(10):4103-4112. https://doi.org/10.13040/ IJPSR.0975-8232.6(10).4103-12

12. Ozaki T, Nakagawara A (2011) Role of p53 in cell death and human cancers. Cancers 3(1):994-1013. https://doi.org/10.3390/cancers3010994

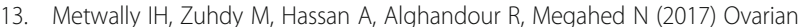
cancer with metastatic inguinal lymphadenopathy: a case series and 
literature review. J Egypt Natl Canc Inst 29(2):109-114. https://doi.org/10.101 6/j.jnci.2017.01.003

14. Bartek J, Lukas J (2007) DNA damage checkpoints: from initiation to recovery or adaptation. Curr Opin Cell Biol 19:238-245

15. Deng C, Zhang P, Harper JW, Elledge SJ, Leder P (1995) Mice lacking p21 $1_{\text {CP1/NAF1 }}$ undergo normal development, but are defective in G1 checkpoint control. Cell 82(4):675-684. https://doi.org/10.1016/0092-8674 (95) $90039-X$

16. Abbas T, Shibata E, Park J, Jha S, Karnani N, Dutta A (2010) CRL4(Cdt2) regulates cell proliferation and histone gene expression by targeting PRSet7/Set8 for degradation. Mol Cell 40(1):9-21

17. Brugarolas J (1995) Radiation induced cell cycle arrest compromised by p21 deficiency. Nature 377(6549):552-557. https://doi.org/10.1038/377552a0

18. Montero J (2019) p21: one protein to rule cell fate. Sci Transl Med 11(499): eaay 3568

19. Shamloo U (2019) p21 in cancer research. Cancers 11(8):1178. https://doi. org/10.3390/cancers11081178

20. Sreevidya N, Mehrotra S (2003) Spectrophotometric method for estimation of alkaloids precipitable with Dragendroff's reagent in plant material. J AOAC Int 86(6):1124-1127. https://doi.org/10.1093/jaoac/86.6.1124

21. Desai A, Xu J, Aysola K, Qin Y, Okoli C, Hariprasad R, Chinemerem U, Gates C, Reddy A, Danner O, Franklin G, Ngozi A, Cantuaria G, Singh K, Grizzle W, Landen C, Partridge EE, Rice VM, Reddy ES, Rao VN (2014) Epithelial ovarian cancer: an overview. World J Transl Medicine 3(1):1-8. https://doi.org/10.5528/wjtm.v3.i1.1

22. Wang H, Khor TO, Shu L, Su ZY, Fuentes F, Lee JH, Kong AN (2012) Plants vs. cancer: a review on natural phytochemicals in preventing and treating cancers and their druggability. Anticancer Agents Med Chem 12(10):12811305. https://doi.org/10.2174/187152012803833026

23. Maplestone RA, Stone MJ, Williams DH (1992) The evolutionary role of secondary metabolites-a review. Gene 115:151-157

24. Hosseini A, Ghorbani A (2015) Cancer therapy with phytochemicals: evidence from clinical studies. Avicenna J Phytomed 5(2):84-97

25. Newman DJ, Cragg GM (2007) Natural products as sources of new drugs over the last 25 years. J Nat Prod 70(3):461-477. https://doi.org/10.1021/ np068054v

26. Taneja SC, Qazi GN (2007) In: Bioactive molecules in medicinal plants: a perspective in their therapeutic action, in Drug discovery and development, In Drug Discovery and Development, M.S. Chorghade (Ed.) pp. 1-50.

27. Okuhara T, Ishikawa H, Urakubo A, Hayakawa M, Yamaki C, Takayama T (2018) Cancer information needs according to cancer type: a content analysis of data from Japan's largest cancer information website. Prev Med Rep 12:245-252

28. Sarraf S, Tejada R, Abawi M, Oberst M, Dennis T, Simon KC (2005) The human ovarian teratocarcinoma cell line PA-1 demonstrates a single translocation: analysis with fluorescence in situ hybridization, spectral karyotyping, and bacterial artificial chromosome microarray. Cancer Genet Cytogenet 161(1):63-69. https://doi.org/10.1016/j.cancergencyto.2005.01.003

29. Shen CJ, Chang CC, Chen YT, Lai CS, Hsu YC (2016) Melatonin suppresses the growth of ovarian cancer cell lines (OVCAR-429 and PA-1) and potentiates the effect of G1 arrest by targeting CDKs. Int J Mol Sci 17(2):176. https://doi.org/10.3390/ijms17020176

30. Sahgal G, Ramanathan S, Sasidharan S, Mordi MN, Ismail S, Mansor SM (2010) Brine shrimp lethality and acute oral toxicity studies on Swieteniama hagoni (Linn.) Jacq. seed methanolic extract. Pharmacog Res 2(4):215-220

31. Vichai V, Kirtikara K (2006) Sulforhodamine B colorimetric assay for cytotoxicity screening. Nat Protoc 1(3):1112-1116. https://doi.org/10.1038/ nprot.2006.179

32. Orellana EA, Kasinski AL (2016) Sulforhodamine B (SRB) assay in cell culture to investigate cell proliferation. Bioprotocol 6(21):e1984

33. Mansouri E, Kooti W, Bazvand M (2015) The effect of hydro-alcoholic extract of Foeniculumvulgare Mill on leukocytes and hematological tests in male rats. Jundishapur J Nat Pharm Prod 10:e1839

34. Jiang WG, Sanders AJ, Katoh M, Ungefroren $H$, Gieseler F, Prince $M$ et al (2015) Tissue invasion and metastasis: molecular, biological and clinical perspectives. Sem Cancer Biol 35:244-275

35. Skehan P, Storeng R, Scudiero D, Monks A, McMahon J, Vistica D, Warren JT, Bokesch H, Kenney S, Boyd MR (1990) New colorimetric cytotoxicity assay for anticancer-drug screening. J Natl Cancer Inst 82(13):1107-1112. https:// doi.org/10.1093/jnci/82.13.1107

36. Kim EM, Jung CH, Kim J, Hwang SG, Park JK, Um HD (2017) The p53/p21 complex regulates cancer cell invasion and apoptosis by targeting $\mathrm{BCl}-2$ family proteins. Cancer Res 77(11):3092-3100. https://doi.org/10.1158/00085472.CAN-16-2098

37. Nakanishi M, Shimada M, Niida H (2006) Genetic instability in cancer cells by impaired cell cycle checkpoints. Cancer Sci 9(7):984-989

\section{Publisher's Note}

Springer Nature remains neutral with regard to jurisdictional claims in published maps and institutional affiliations.

\section{Submit your manuscript to a SpringerOpen ${ }^{\circ}$ journal and benefit from:}

- Convenient online submission

- Rigorous peer review

- Open access: articles freely available online

- High visibility within the field

- Retaining the copyright to your article

Submit your next manuscript at $\boldsymbol{\nabla}$ springeropen.com 